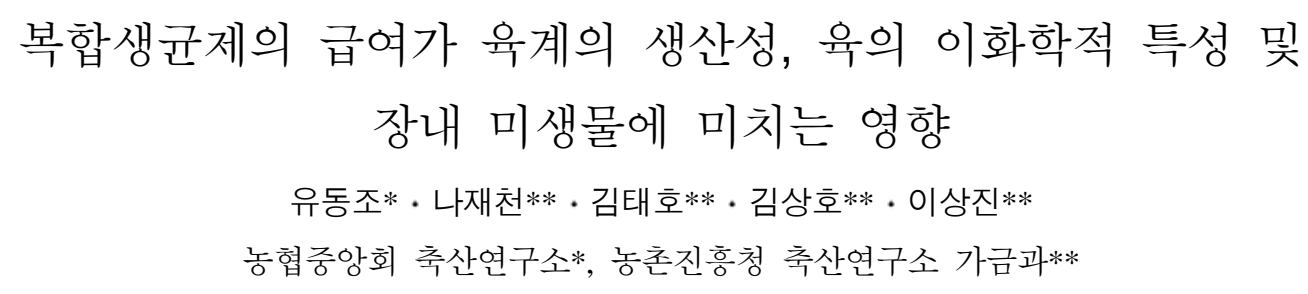

\title{
Effect of Supplementation of Complex Probiotics on Performances, Physio-chemical Properties of Meat and Intestinal Microflora in Broiler
}

\author{
D. J. Yu*, J. C. Na**, T. H. Kim**, S. H. Kim** and S. J. Lee** \\ Livestock Research Institute, National Agricultural Cooperative Federation* \\ Division of Poultry, National Livestock Research Institute**
}

\begin{abstract}
A feeding trial was carried out to investigate the effect of supplemental complex probiotics on performances, physio-chemical properties of meat and inetestinal microflora in broiler chicks.

Four hundred eighty broiler chickens, one days old with mixed sexes were fed one of four diets containing $0,0.1,0.2$ and $0.4 \%$ complex probiotics for 7 weeks. There were four replicates with thirty chicks per pen. Diet contained ME 3,100,3,100kcal $/ \mathrm{kg}$, and CP 22.0, 20.0\% for starting and finishing period, respectively. Body Weight gain of chicks fed the complex probiotics tended to increase from the frist week and all complex probiotics higher than control from the 4th week. Chickens fed the diets containing $0.2 \%$ probiotics had higher $(\mathrm{P}<0.05)$ than those fed the other levels from the 4th week to 5th week. Feed conversion also improved significantly $(\mathrm{P}<0.05)$ in the supplemental $0.2 \%$ probiotics from the 4 th week to 5 th week. In physio-chemical properties of meat, carcass rate increased significantly $(\mathrm{P}<0.05)$ in the supplemental $0.4 \%$ probiotics compared to that of control at 7 weeks overall means and abdominal fat pad rate increased significantly $(\mathrm{P}<0.05)$ in the supplemental $0.2 \%$ probiotics compared to that of control. Cooking loss decreased significantly $(\mathrm{P}<0.05)$ in the supplemental all probiotics. But shear force increased significantly $(\mathrm{P}<0.05)$ in the supplemental $0.4 \%$ probiotics. The number of ileum and cecum Lactobacillus spp. tended to increase in the supplemental complex probiotics at 7 week of age, but was not significantly different.

As the result, supplemental complex probiotics increased performance and physio-chemical properties of meat and the number of intestinal Lactobacillus of broiler chicks.
\end{abstract}

(Key words : Complex probiotics, Broiler chicks, Lactobacillus, Performance, Intestinal microflora)

$\begin{array}{cl}\mathrm{I} \text { 서 론 } & \begin{array}{c}\text { 부터 유래되어 서식하게 되는데, } 1 \text { 주령이 되면 } \\ \text { 미생물의 구성이 어느 정도 안정된다(Fuller, }\end{array} \\ \text { 가금의 장내 미생물은 부화 후 주위 환경으로 } & 1989) . \text { 이와 같이 성장 중에 정상적으로 형성된 }\end{array}$ Corresponding author: D. J. Yu, Livestock Research Institute, National Agricultural Cooperative Federation, San 54
Sindu, Gongdo Anseong, Gyeonggi 456-824, Korea. Phone : +82-31-653-0239, E-mail :
yudongjo@hanmail.net 
장내 미생물총에는 Lactobacilli, Bifidobacterium, Bacilli, Streptococci 등과 같이 영양소의 이용성 을 증진시키거나, 병원성 미생물의 집락을 억 제하는 등 숙주에게 유리한 작용을 하는 균들 이 우점하게 된다. 그러나 가금이 환경적 - 영 양적 스트레스를 받으면 유해한 미생물의 감염 에 의해 정상적인 장내 미생물총의 균형이 깨 져서, 성장률 및 사료 이용성 감소 등의 경제 적 손실을 초래하게 된다.

가금의 생산성을 향상시키기 위해서 항생제 를 비롯한 각종 성장촉진제의 개발이 꾸준히 이루어지고 있다. 항생제는 연용하게 되면 내 성을 지니는 미생물이 증가하여 그 항생제의 효능이 떨어지거나, 항생제가 축산물에 잔류 하는 등의 문제 때문에, 현재 유럽 등지에서 는 항생제를 치료용으로만 사용하게끔 되어 있다. 이에 대한 대안으로 장내에서 유해세균 의 증식을 억제하고, 가금의 성장촉진 효과와 생산성 향상 효과가 있는 생균제를 개발하기 위한 연구가 활발히 진행되고 있다. 생균제는 장내 미생물의 균형을 개선함으로써 숙주에 유익한 작용을 하는 살아있는 미생물 사료첨 가제로 알려져 있는 것과 같이(Fuller, 1989), 여러 가지 스트레스로 인하여 발생될 수 있는 장내 미생물총의 불균형을 방지하는 역할을 한다.

이제까지 생균제로서 Lactobacilli가 가장 많 이 연구되어 왔다. 육계에게 유산균을 급여하 므로써 생산성을 향상시켰다는 보고들(Tortuero, 1973; Jin 등, 1996; 박, 2001)이 다수 있으며, 현재도 새로운 균주가 계속 개발 중에 있다. 그러나 Watkins와 Kratzer(1983), Maiolino 등 (1992)은 육계에서 유산균 계통의 생균제 급여 가 대조구와 차이가 없었다고 보고한 바 있다. Gilliland(1987)는 이와 같은 유산균 계통 생균 제의 급여효과가 일치하지 않는 것은 주로 미 생물의 부정확한 배양과 관계가 있다고 하였으 며, Jin 등(1998)은 첨가되는 균주의 종류와 첨 가방법에 따라서도 차이가 날 수 있다고 하였 다. 또한 좋은 환경에서는 스트레스 요인이 적 어짐에 따라 그 차이가 크게 나타나지 않은 것
으로 알려져 있다. 이와 같이 유산균의 급여가 효과를 나타나지 않는 원인은 급여되는 유산균 종 간의 차이, 급여시 유산균의 활력, 급여수준 그리고 환경적 요인 등의 차이에서 기인한 것 으로 생각되어지며, 장관내에 존재하는 복잡하 고 다양한 미생물군에 대한 정보가 아직 부족 하여 실제로 장관내에서 바람직한 효과를 발휘 할 수 있는 균종을 확인하지 못한데 있다고 여 겨진다.

따라서 본 연구에서는 복합생균제의 수준별 급여가 육계의 생산성, 장내 미생물 변화 및 육 질에 미치는 영향을 구명하고자 실시하였다.

\section{ㅍ 재료 및 방법}

\section{1. 공시계 및 시험기간}

본 시험의 공시계는 육계초생추 Cobb로서 시 험직전 모든 개체에 대한 체중을 측정하여 $45.2 \mathrm{~g}$ 내외의 건강한 병아리 480수를 이용하였 으며, 축산기술연구소 가금과 평사시험계사에 서 2002년 7월 3일부터 2002년 8월 20까지 7주 간 사양시험을 실시하였다.

\section{2. 시험설계}

본 시험은 복합 생균제의 육계 급여효과를 구명하기 위해 Table 1에서 보는 바와 같이 대 조구와 사료에 복합 생균제를 각각 $0.1 \%, 0.2 \%$ 및 $0.4 \%$ 수준으로 첨가한 3 개의 첨가구로 총 4 개의 시험구를 두었다. 사양시험을 위해 각 처 리당 4반복으로 하였고, 반복당 감별된 암-수 15씩 30수, 총 480수를 공시하였다.

Table 1. Experimental design

\begin{tabular}{lrrrr}
\hline \multirow{2}{*}{ Items } & \multicolumn{4}{c}{ Supplemental levels of } \\
& complex & probiotics(\%) \\
\cline { 2 - 5 } & Control & 0.1 & 0.2 & 0.4 \\
\hline \hline No. of replication & 4 & 4 & 4 & 4 \\
Birds / replicate & 30 & 30 & 30 & 30 \\
Total No. chicken & 120 & 120 & 120 & 120 \\
\hline
\end{tabular}




\section{3. 사양관리}

본 시험의 공시계가 수용된 계사는 윈치커텐 과 콘크리트 바닥이 설치된 개방식계사이며, 각 pen의 크기는 $2 \times 3 \mathrm{~m}\left(6 \mathrm{~m}^{2}\right)$ 였다. 깔짚은 왕겨 를 이용하였으며 각 pen당 사용량은 $37 \mathrm{~kg}$ 정 도로서 $5 \mathrm{~cm}$ 두께였다. 온도 조절은 입추시 $35^{\circ} \mathrm{C}$ 를 기준으로 매일 $1{ }^{\circ} \mathrm{C}$ 씩 낮추어 상온과 동일한 10 일령에 폐온시켰다. 습도는 입추시 $65 \sim 70 \%$ 로 조정하였고 이후 $60 \%$ 정도로 유 지하다가 폐온시부터 외부 습도와 동일하게 사육하였다.

점등은 입추후 3 일간 24 시간 점등을 실시하 였고, 이후 7일령까지 23시간 점등:1시간 소등 으로 하였으며 8일령부터 시험종료시까지 야간 간헐점등 $1 \mathrm{~L}: 2 \mathrm{D}$ 로 실시하였다. 광도는 시험 전기간 $10 \sim 15 \mathrm{Lux}$ 였다. 백신은 1일령에 $\mathrm{ND}+$ $\mathrm{IB}$ 혼합백신은 분무접종, $\mathrm{MD}$ 는 피하주사로 접 종하였으며, 7일령에 IBD, 11일령에 $\mathrm{ND}+\mathrm{IB}$, 14 일령에 IBD, 21일령에 ND, 28일령에 IBD를 각각 음수 접종하였다.

사료는 신선한 균을 급여하기 위하여 매주 첨가수준별로 충분히 혼합하여 급여하였고, 물 은 신선한 것으로 자유롭게 섭취할 수 있도록 하였으며, 기타 사양관리는 축산기술연구소 가 금과 관행에 준하여 실시하였다.

\section{4. 시험사료 및 복합 생균제}

본 시험에 사용된 시험사료는 $\mathrm{NRC(1994)}$ 육계의 성장단계별 영양소 요구량 권장수준 에 준하여 제조하였다. 영양소 수준을 starter (0 3주령)와 grower(4 7주령)로 구분하여 배 합하였으며, $\mathrm{ME}$ 는 전기간 $3,100 \mathrm{kcal} / \mathrm{kg}, \mathrm{CP}$ 는 전기 $22.0 \%$, 후기 $20.0 \%$ 였다. 시험사료는 옥 수수와 대두박 위주였고 유지는 옥수수유를 사용하였으며 항생제는 전기간 배제하였다. 사료배합은 유지사료 산패를 고려하여 7일 간격으로 실시하였으며, 수직형 배합기 $(200 \mathrm{~kg}$, 국산)를 이용하여 4 분씩 배합하였다.
첨가제로 이용된 복합 생균제는 대전광역시 대덕구 소재 (주)한국바이오스에서 제조 공급 하였다.

본 연구에 이용된 시험사료의 성분 함량, 화 학적 조성 및 생균제의 조성은 Table 2와 Table 3에 나타낸 바와 같다.

Table 2. Formula and chemical composition of experimental diets

\begin{tabular}{lrr}
\hline Item & $\begin{array}{r}\text { Starter } \\
(0-3 w k)\end{array}$ & $\begin{array}{r}\text { Grower } \\
(4-7 w k)\end{array}$ \\
\hline \hline Ingredients composition & & \\
$\quad$ Corn & 53.29 & 61.65 \\
Soybean meal(CP, 44\%) & 33.91 & 27.88 \\
Corn gluten meal(CP, 60\%) & 4.01 & 4.00 \\
Soybean oil & 4.73 & 3.06 \\
Tricalcium phosphate & 0.27 & 0.07 \\
Limestone & 0.02 & 0.05 \\
DL-Methionine 50 & 2.00 & 1.23 \\
L-Lysine 80 & 1.02 & 1.31 \\
Salts & 0.25 & 0.25 \\
Vit.-Min. premix* & 0.50 & 0.50 \\
\hline
\end{tabular}

\section{Chemical composition**}

$\begin{array}{lrr}\text { ME, kcal/kg } & 3,100 & 3,100 \\ \text { CP, \% } & 22.00 & 20.00 \\ \text { Ca, \% } & 1.00 & 0.90 \\ \text { Non phytate phosphorus, \% } & 0.45 & 0.35 \\ \text { Lysine, \% } & 1.10 & 1.00 \\ \text { Methionine \% } & 0.50 & 0.38\end{array}$

* Contained followings per $\mathrm{kg}$ diet : Vit. A 1,600,000IU, Vit. $D_{3}$ 300,000IU, Vit. E 800IU, Vit. $\mathrm{K}_{3}$ 132mg, Vit. $\mathrm{B}_{2}$ 1,000mg, Vit. $\mathrm{B}_{12}$ 1,200mcg, niacin 2,000mg, pantothenate calcium $800 \mathrm{mg}$, folic acid 60mg, choline chloride 35,000mg, DL-methionine $6,000 \mathrm{mg}$, iron 4,000mg, copper 500mg, manganese $12,000 \mathrm{mg}$, zinc $9,000 \mathrm{mg}$, cobalt $100 \mathrm{mg}$, BHT 6,000mg, iodide 250mg.

** Calculated values. 
Table 3. The number of microflora population and chemical composition of complex probiotics

\begin{tabular}{lc}
\hline Item & Contents \\
\hline \hline Number of microflora(cfu/g) & \\
Lactobacillus spp. & $5.0 \times 10^{8}$ \\
Saccharomyces cerevisiae & $2.5 \times 10^{7}$ \\
Enterococcus faecallis & $5.0 \times 10^{8}$ \\
Phototrophic bacteria & $2.5 \times 10^{8}$ \\
Bacillus spp. & $2.5 \times 10^{7}$ \\
\hline Chemical composition(DM basis) & \\
Dry matter(\%) & 82.53 \\
Crude protein(\%) & 16.14 \\
Ether extract(\%) & 15.23 \\
Crude fiber(\%) & 5.64 \\
Crude ash(\%) & 8.76 \\
\hline
\end{tabular}

\section{5. 조사항목 및 조사방법}

\section{(1) 생산성 조사}

체중은 입추시와 매주 측정하였는데, 반복별 전체중량을 칭량하여 개체수로 나누어 평균체 중을 측정하였다. 사료섭취량은 주간별로 누적 사료섭취량으로 조사하였고, 사료요구율은 사 료섭취량을 증체량으로 나누어 주간별 누적 사 료요구율로 계산하였다. 폐사된 개체는 발견 즉시 제거하였으며 주간별로 나누어 육성율로 표시하였다.

\section{(2) 육의 이화학적 특성조사}

육의 이화학적 특성조사를 위하여, 시험 종 료시 각 처리구별로 암-수 5수씩을 도살하여 실시하였다. 도체율은 생체중에 대한 방혈탈모 후 도체중의 비율로 나타내었으며, 복강지방축 적율은 복강부위와 근위부위의 지방을 잘 분리 하여 도체중에 대한 비율로 나타내었다.

계육의 육질은 가열 감량(Cooking loss)과 전 단력(Shear force)을 측정하였는데, 가열 감량은 계육을 $2 \mathrm{~cm}$ 두께로 일정하게 절단하여 무게를 측정하고, 알루미늄 호일로 싸서 외부온도 $200^{\circ} \mathrm{C}$
인 오븐을 이용하여 심부 온도가 $71^{\circ} \mathrm{C}$ 에서 도 달 한 후 1 시간 가열한 다음 냉각시켜 감량된 무게를 측정하여 나타내었다. 전단력은 가열 감량 실험 후 방냉된 고기를 직경 $1.27 \mathrm{~cm}$ 의 원통형 절편으로 만들어 Instron Universal Testing Machine(Model 1000)을 이용하여 0.00을 맞춘 다음 시료가 완전히 절단될 때 수치를 측 정하여 나타내었으며, 가열 감량과 전단력은 축 산기술연구소 축산물이용과에서 실시하였다.

(3) 장내미생물 조사

시험 종료시 장내 미생물을 조사하기 위하여, 각 처리구별로 4수씩을 경골탈퇴법으로 희생시 켰으며, 회장내용물은 Meckel's diverticulum 부 위에서 아래쪽으로 $5 \mathrm{~cm}$ 정도 절단하여 채취하 였다. 맹장은 두 개의 맹장내용물 전체에서 장 내용물을 무균적으로 채취하였다. 각각의 장내 용물들은 생리적식염수를 이용하여 $10^{-11}$ 까지 계단희석하였다. Lactobacillus spp., Salmonella, E. coli, 혐기성미생물의 수를 측정하기 위하여 평판배지에 희석액 중 $10^{-5}, 10^{-7}, 10^{-9}, 10^{-11}$ 을 $0.02 \mathrm{~mL}$ 씩 분주하여 접종하였다. Lactobacillus spp.은 Rogosa agar(Difco)를, Salmonella는 SS agar를, E. coli는 MacConkey agar(Difco)를, 혐기 성미생물은 anaerobic agar를 이용하여 $37^{\circ} \mathrm{C}$ 에서 48시간 또는 24시간 호기적으로 배양한 후, colony 수를 조사하였다.

\section{6. 통계분석}

본 시험에서 얻어진 시험 결과들은 SAS package(SAS Institute, 1996)의 GLM procedure로 분산분석을 실시하고, 처리간 유의성 검정은 Duncan's new multiple range test를 이용하여 95\% 수준에서 유의성 분석을 실시하였다.

\section{III 결과 및 고찰}

\section{1. 생산성}

복합생균제의 첨가수준에 대한 육계의 주령 
별 체중변화는 Table 4에 나타내었다. 급여 후 3주령까지 생균제 $0.1 \%, 0.2 \%, 0.4 \%$ 첨가구에 서 대조구에 비하여 통계적 유의차는 없었다. 그러나 4주령부터 모든 첨가구가 무첨가구에 비하여 무거운 경향을 보였는데, 특히 6주령에 서 체중은 유의적인 차이를 보였으며 $(\mathrm{P}<0.05)$ 1 주령과 2주령에서 증체효과를 보이지 않던 $0.2 \%$ 첨가구가 체중이 $2,222 \mathrm{~g}$ 으로 무첨가구에 비하여 $90 \mathrm{~g}$ 정도 무거운 것으로 나타났다. 시험 종료시인 7주령의 체중은 모든 첨가구에서 무 첨가구에 비하여 각각 $2,715 \mathrm{~g}, 2,722 \mathrm{~g}$ 및 $2,689 \mathrm{~g}$ 으로써 무겁게 나타났으나 유의성은 인정되지
않았다. 이것은 주령이 증가함에 따라 반복간의 차이가 크게 발생하여 나타난 결과로 사료된다.

Table 5와 Table 6에서는 복합생균제의 첨가 에 의한 증체효과를 나타내었다. 특히 Table 6 에서 보는 바와 같이 $4 \sim 5$ 주령간 비교에서 $0.2 \%$ 첨가구가 무첨가구에 비하여 약 $58.3 \mathrm{~g}$ 증 체 효과를 보였다 $(\mathrm{P}<0.05)$. 그러나 전체적인 비교에서 복합생균제 첨가구와 무첨가구는 통 계적 유의차가 없었는데, 이러한 결과는 생균 제 급여시 오히려 증체가 개선되지 않았다는 Burkett 등(1977), Watkins와 Kratzer(1983; 1984), Maiolino 등(1992), 노 등(1994), $\mathrm{Yeo}$ 와 Kim

Table 4. Effect of supplementation of complex probiotics on body weight in broiler chicks

\begin{tabular}{lccccccc}
\hline \multirow{2}{*}{ Treatments* } & \multicolumn{7}{c}{ Weeks } \\
\cline { 2 - 8 } & Initial wt. & 1 & 2 & 3 & 4 & 5 & 6 \\
\hline \\
\hline
\end{tabular}

* Supplemental levels of complex probiotics(\%).

${ }^{\mathrm{a}, \mathrm{b}}$ Values with different superscripts in the same columns differ significantly $(\mathrm{P}<0.05)$.

Table 5. Effect of supplementation of complex probiotics on weekly body weight gain in broiler chicks

\begin{tabular}{|c|c|c|c|c|c|c|c|}
\hline \multirow{2}{*}{ Treatments* } & \multicolumn{7}{|c|}{ Weeks } \\
\hline & 1 & 2 & 3 & 4 & 5 & 6 & 7 \\
\hline Control & 94.3 & 228.7 & 336.7 & 383.4 & $439.7^{\mathrm{ab}}$ & 603.7 & 534.0 \\
\hline 0.1 & 96.4 & 230.4 & 335.6 & 427.3 & $408.8^{\mathrm{b}}$ & 641.9 & 529.8 \\
\hline 0.2 & 94.5 & 227.1 & 340.4 & 402.9 & $478.5^{\mathrm{a}}$ & 633.7 & 499.3 \\
\hline 0.4 & 96.1 & 235.7 & 327.8 & 413.3 & $446.2^{\mathrm{ab}}$ & 616.7 & 507.8 \\
\hline SEM & 1.101 & 1.513 & 3.817 & 9.344 & 9.622 & 9.331 & 11.735 \\
\hline
\end{tabular}

* Supplemental levels of complex probiotics(\%).

${ }^{\mathrm{a}, \mathrm{b}}$ Values with different superscripts in the same columns differ significantly $(\mathrm{P}<0.05)$. 
(1997)의 보고와 동일하였다. 이것은 시험환경 이 좋아 스트레스 요인이 적어짐에 따라 그 차 이가 없었던 것으로 생각되는데, Gilliland(1987) 는 생균제 급여시 차이가 나타나는 이유는 주 로 미생물의 부정확한 배양과 관계가 있다고 하였으며, Jin 등(1998)은 첨가되는 균주의 종류 와 첨가방법에 따라서도 차이가 날 수 있다고 하였다.

처리간 사료섭취량과 시료요구율은 Table 7 과 Table 8에서 보는 바와 같다. $0 \sim 3$ 주령까지 의 누적사료섭취량은 대조구, $0.1 \%, 0.2 \%$ 및 $0.4 \%$ 첨가구가 각각 $998 \mathrm{~g}, 1,047 \mathrm{~g}, 1,032 \mathrm{~g}$ 및 $1,015 \mathrm{~g}$ 으로써 복합생균제 첨가구가 무첨가구에 비해 많은 사료섭취량을 보였고, $4 \sim 5$ 주령에 서는 $0.2 \%$ 첨가구와 $0.4 \%$ 첨가구의 누적사료섭 취량이 다소 많았으나 통계적 유의차가 인정되 지 않았다. 이러한 것은 복합생균체 첨가구가 체중 증가가 높아지면서 섭취량 또한 많아졌기 때문이고, 전체 누적사료섭취량은 처리간에 유 의성은 없었으나 복합생균제 첨가구가 다소 적 게 섭취되었던 것으로 나타났다. 주령별 사료 요구율은 $4 \sim 5$ 주령에서 $0.2 \%$ 첨가구가 무첨가 구에 비하여 유의적으로 개선된 것으로 나타났 다 $(\mathrm{P}<0.05)$. 전체적으로도 통계적 유의성은 없 었으나 복합생균제 첨가구가 무첨가구에 비하 여 다소 개선된 것으로 나타났다.

이러한 결과는 김 등(2000)이 육계맹장 유래 유산균을 급여한 결과 체중이 무첨가에 비하여 증가하였다는 보고와 비슷하였고, Jin 등(1998) 도 가금소화기관 유래 유산균을 육계에 급여시 증체향상이 되었다고 하였으며, Mohan 등 (1996)은 L. acidophilus, L. casei, Bifidobacterium bifidum, Aspergillus oryzae, Torulopsis 혼합물이 포함된 생균제 $100 \mathrm{mg} / \mathrm{kg}$ 을 첨가 했을 때 증체 량이 5 9\% 증가했다고 보고하여 본 연구 결 과와 비슷하였다.

그리고, 생균제를 첨가급여 하였을 때 사료섭 취량 및 사료요구율이 개선되는 경향이 있었다 고 보고한 Chiang와 Hsieh(1995), Arends(1981), 류와 박(1998) 및 김 등(2000)의 연구와 유사한 결과를 나타내었다.
Table 6. Effect of supplementation of complex probiotics on body weight gain in broiler chicks

\begin{tabular}{cclrr}
\hline \multirow{2}{*}{ Treatments* } & \multicolumn{4}{c}{ Weeks } \\
\cline { 2 - 5 } & $0 \sim 3$ & $4 \sim 5$ & $6 \sim 7$ & Overall \\
\hline \hline \multirow{2}{*}{ Control } & $\cdots \cdots \cdots \cdots \cdots \cdots \cdots \cdots \cdots \cdots$ & g/chick $\cdots \cdots \cdots \cdots \cdots \cdots \cdots \cdots$ \\
0.1 & 659.7 & $823.1^{\mathrm{b}}$ & 1,138 & 2,620 \\
0.2 & 662.4 & $836.0^{\mathrm{ab}}$ & 1,172 & 2,670 \\
0.4 & 662.0 & $881.4^{\mathrm{a}}$ & 1,133 & 2,676 \\
SEM & 659.6 & $859.5^{\mathrm{ab}}$ & 1,125 & 2,643 \\
\hline
\end{tabular}

* Supplemental levels of complex probiotics(\%).

${ }^{\mathrm{a}, \mathrm{b}}$ Values with different superscripts in the same columns differ significantly $(\mathrm{P}<0.05)$.

Table 7. Effect of supplementation of compound probiotics on feed intake in broiler chicks

\begin{tabular}{|c|c|c|c|c|}
\hline \multirow{2}{*}{ Treatments* } & \multicolumn{4}{|c|}{ Weeks } \\
\hline & $0 \sim 3$ & $4 \sim 5$ & $6 \sim 7$ & Overall \\
\hline & \multicolumn{4}{|c|}{ 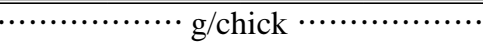 } \\
\hline Control & 998 & 1,795 & $2,622^{\mathrm{a}}$ & 5,415 \\
\hline 0.1 & 1,047 & 1,781 & $2,582^{\mathrm{a}}$ & 5,410 \\
\hline 0.2 & 1,032 & 1,802 & $2,579^{\mathrm{a}}$ & 5,412 \\
\hline 0.4 & 1,015 & 1,822 & $2,435^{b}$ & 5,272 \\
\hline SEM & 10.959 & 15.165 & 25.095 & 31.762 \\
\hline
\end{tabular}

* Supplemental levels of complex probiotics(\%).

${ }^{\mathrm{a}, \mathrm{b}}$ Values with different superscripts in the same columns differ significantly $(\mathrm{P}<0.05)$.

Table 8. Effect of supplementation of compound probiotics on feed conversion in broiler chicks

\begin{tabular}{cllll}
\hline \multirow{2}{*}{ Treatments* $^{*}$ Weeks } \\
\cline { 2 - 5 } & $0 \sim 3$ & $4 \sim 5$ & $6 \sim 7$ & Overall \\
\hline \hline \multirow{2}{*}{ Control } & $1.513^{\mathrm{b}}$ & $2.183^{\mathrm{a}}$ & 2.307 & 2.067 \\
0.1 & $1.581^{\mathrm{a}}$ & $2.132^{\mathrm{ab}}$ & 2.206 & 2.026 \\
0.2 & $1.559^{\mathrm{ab}}$ & $2.044^{\mathrm{b}}$ & 2.278 & 2.022 \\
0.4 & $1.538^{\mathrm{ab}}$ & $2.121^{\mathrm{ab}}$ & 2.170 & 1.995 \\
SEM & 0.011 & 0.019 & 0.026 & 0.012 \\
\hline
\end{tabular}

* Supplemental levels of complex probiotics(\%).

${ }^{\mathrm{a}, \mathrm{b}}$ Values with different superscripts in the same columns differ significantly $(\mathrm{P}<0.05)$. 
Table 9. Effect of supplementation of complex probiotics on carcass rate and abdominal fat pad rate in broiler chicks at 7 weeks

\begin{tabular}{cccccccc}
\hline \multirow{2}{*}{ Treatments* } & \multicolumn{3}{c}{ Carcass } & \multicolumn{3}{c}{ A. F. P } \\
\cline { 2 - 3 } \cline { 5 - 7 } & Female & Male & Mean & & Female & Male & Mean \\
\hline \hline Control & 71.1 & $72.6^{\mathrm{ab}}$ & $71.5^{\mathrm{b}}$ & & 1.98 & $1.61^{\mathrm{a}}$ & $1.79^{\mathrm{a}}$ \\
0.1 & 72.1 & $72.8^{\mathrm{ab}}$ & $72.4^{\mathrm{ab}}$ & & 2.00 & $1.30^{\mathrm{ab}}$ & $1.65^{\mathrm{ab}}$ \\
0.2 & 72.2 & $71.6^{\mathrm{b}}$ & $71.9^{\mathrm{ab}}$ & & 1.58 & $1.05^{\mathrm{b}}$ & $1.31^{\mathrm{b}}$ \\
0.4 & 73.2 & $73.8^{\mathrm{a}}$ & $73.5^{\mathrm{a}}$ & & 1.27 & $1.60^{\mathrm{a}}$ & $1.40^{\mathrm{b}}$ \\
SEM & 0.351 & 0.298 & 0.295 & & 0.140 & 0.089 & 0.063 \\
\hline
\end{tabular}

* Supplemental levels of complex probiotics(\%).

${ }^{\mathrm{a}, \mathrm{b}}$ Values with different superscripts in the same columns differ significantly $(\mathrm{P}<0.05)$.

본 시험에서 육계후기에 그 효과가 크게 나 타난 것은 육계 초기부터 급여된 복합 생균제 가 육계후기에 그 균총이 장내에 정착하게 됨 으로 장내 유해세균의 수를 감소시키고, 영양 소 흡수에 최적의 조건을 조성하도록 하였기 때문인 것으로 보여진다.

\section{2. 육의 이화학적 특성}

도체율, 복강지방축적율 및 계육의 육질 비 교는 Table 9 과 Table 10에서 보는 바와 같다. 도체율은 암수 전체 평균에서 $0.4 \%$ 첨가구가 무첨가구에 비해 $2.80 \%(\mathrm{P}<0.05)$ 더 생산되었으 며, 복강지방축적율은 $0.2 \%$ 첨가구 수컷에서 만 유의적으로 개선되었으며 $(\mathrm{P}<0.05)$, 전체 평균에서는 $0.2 \%$ 첨가구와 $0.4 \%$ 첨가구가 무 첨가구에 비하여 복강지방축적율이 낮았으며 $(\mathrm{P}<0.05)$, 특히 $0.2 \%$ 첨가구가 상당히 개선된 것으로 나타났다.

계육의 육질조사에서는 가열 감량(Cooking loss)과 전단력(Shear force)을 측정하였는데, 가 열 감량은 무첨가구, $0.1 \%, 0.2 \%$ 및 $0.4 \%$ 첨가 구가 각각 $22.3 \%, 15.8 \%, 14.9 \%$ 및 $17.1 \%$ 로 무 첨가구에 비하여 유의적으로 낮은 감량을 나타 내어 $(\mathrm{P}<0.05)$ 개선된 효과를 보였다.

전단력은 각각 $2.6 \mathrm{~kg} / \mathrm{cm}^{2}, 2.8 \mathrm{~kg} / \mathrm{cm}^{2}, 2.2 \mathrm{~kg} / \mathrm{cm}^{2}$ 및 $3.4 \mathrm{~kg} / \mathrm{cm}^{2}$ 으로 $0.4 \%$ 첨가구는 오히려 높게 나타 났는데, 생균제 첨가로 인한 계육의 육질변화는 더 많은 연구가 이루어져야 할 것으로 생각된다.
Table 10. Effect of supplementation of complex probiotics on cooking loss and shear force in broiler chicks at 7 weeks

\begin{tabular}{ccc}
\hline Treatments* & Cooking loss(\%) & Shear \\
\hline \hline Control & $22.3^{\mathrm{a}}$ & $2.6^{\mathrm{b}}$ \\
0.1 & $15.8^{\mathrm{b}}$ & $\left.2 . \mathrm{cm}^{\mathrm{b}}\right)$ \\
0.2 & $14.9^{\mathrm{b}}$ & $2.2^{\mathrm{b}}$ \\
0.4 & $17.1^{\mathrm{b}}$ & $3.4^{\mathrm{a}}$ \\
SEM & 0.240 & 1.029 \\
\hline
\end{tabular}

* Supplemental levels of complex probiotics(\%).

${ }^{\mathrm{a}, \mathrm{b}}$ Values with different superscripts in the same columns differ significantly $(\mathrm{P}<0.05)$.

\section{3. 장내미생물 변화}

회장과 맹장내 7주령의 Lactobacillus spp., Salmonella, E. coli 및 혐기성미생물의 수는 Table 11과 Table 12에서 보는 바와 같다. 전체 적으로 처리간에 통계적인 유의성은 없었으나, 회장과 맹장내의 유산균 수에 있어서는 무첨가 구에 비하여 복합생균제 첨가구가 다소 증가하 였는데, 이러한 결과는 Jin 등(1996)이 10일령의 육계에 Lactobacilli를 사료에 첨가하여 급여시 유익한 미생물인 유산균 수가 장내에 증가하였 으며, 김 등(2000)이 맹장 유래 유산균을 급여 하면 1 주령에 유의성은 없었으나 맹장내의 유 산균이 증가하는 경향이 나타났으며, 남궁 등 (1986)이 육계에 생균제를 급여함으로써 소장에 서 Lactobacilli의 수가 증가하는 것으로 나타난 
Table 11. Influence of supplemental complex probiotics on ileum microflora in broiler chicks at 7 weeks

\begin{tabular}{|c|c|c|c|c|}
\hline \multirow{2}{*}{ Treatments* } & \multicolumn{4}{|c|}{ Ileum } \\
\hline & Lactobacillus & Salmonella & E. coli & Anaerobe \\
\hline & 年 & $\cdots \cdots \cdot \log _{10}$ & at $\cdots \cdot$ & 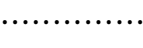 \\
\hline Control & 7.690 & 5.375 & 7.435 & 11.109 \\
\hline 0.1 & 8.599 & 5.482 & 7.386 & 11.346 \\
\hline 0.2 & 8.980 & 5.834 & 7.728 & 10.685 \\
\hline 0.4 & 8.748 & 5.219 & 7.914 & 10.957 \\
\hline SEM & 0.311 & 0.142 & 0.216 & 0.231 \\
\hline
\end{tabular}

* Supplemental levels of complex probiotics(\%).

Table 12. Influence of supplemental complex probiotics on cecum microflora in broiler chicks at 7 weeks

\begin{tabular}{|c|c|c|c|c|}
\hline \multirow{2}{*}{ Treatments* } & \multicolumn{4}{|c|}{ Cecum } \\
\hline & Lactobacillus & Salmonella & E.coli & Anaerobe \\
\hline & \multicolumn{4}{|c|}{ 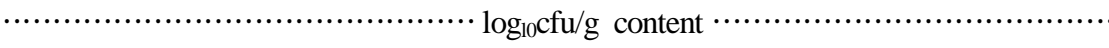 } \\
\hline Control & 8.570 & 6.351 & 7.606 & 11.151 \\
\hline 0.1 & 9.416 & 7.877 & 8.834 & 11.736 \\
\hline 0.2 & 9.539 & 6.644 & 8.368 & 10.816 \\
\hline 0.4 & 9.521 & 6.513 & 8.224 & 10.167 \\
\hline SEM & 0.222 & 0.271 & 0.245 & 0.245 \\
\hline
\end{tabular}

* Supplemental levels of complex probiotics(\%).

다고 보고한 것과 비슷하였다.

이와 같이 생균제의 급여로 인한 유익균의 증가는 장내에서 유기산 생성에 의한 $\mathrm{pH}$ 저하 및 각종 항생물질을 생성하여 병원성 미생물을 억제하며(White 등, 1969; Cranwell 등, 1976; Juven 등, 1991), 단백질 및 당 분해효소를 생성 하여 영양소의 소화 및 흡수를 증진시켜주는 역할을 한다. 그러므로 유산균과 같이 유익한 미생물의 증가로 인하여 육계의 생산성이 개선 되는 것으로 사료된다.

$$
\text { IV 요 약 }
$$

본 연구는 복합생균제의 급여가 육계의 생산 성, 육의 이화학적 특성 및 장내미생물에 미치 는 영향을 구명하고 실시하였다. 공시계는 육 계초생추 Cobb 480수를 이용하였으며 평사에서
7주간 사육하였다. 시험사료에 첨가된 복합생 균제의 첨가수준은 $0.1 \%, 0.2 \%, 0.4 \%$ 였으며 기 초사료 영양소 함량은 사육전기 $(0 \sim 3$ 주 $)$ 에 $\mathrm{ME}$ $3,100 \mathrm{kcal} / \mathrm{kg}, \mathrm{CP} 22.0 \%$, 후기(4 7주)에는 각각 $3,100 \mathrm{kcal} / \mathrm{kg}, 20.0 \%$ 로 하였다.

복합생균제의 급여에 의한 육계의 주령별 체 중변화는 4주령까지는 첨가구와 대조구간에 차 이를 나타내지 않았는데, 5주령에서는 $0.2 \%$ 첨 가구만 대조구와 유의적인 차이를 보였으나 $(\mathrm{P}<0.05), 6$ 주령에서는 모든 첨가구가 대조구보 다 유의적으로 무거웠다 $(\mathrm{P}<0.05)$.

사료섭취량은 전기간에서는 통계적인 유의성 은 없었으나 $6 \sim 7$ 주령에 $0.4 \%$ 첨가구가 대조 구보다 유의적으로 적게 섭취하였으며 $(\mathrm{P}<0.05)$, 사료요구율은 $4 \sim 5$ 주령에 $0.2 \%$ 첨가구가 대조 구에 비하여 유의적으로 개선되었으나 $(\mathrm{P}<0.05)$, 전 시험기간 동안에는 복합생균제의 첨가에 의 
한 차이를 나타내지 않았다.

7주령시 도체율은 암 · 수 전체평균에서 $0.4 \%$ 첨가구가 무첨가구에 비해 $2.80 \%$ 증가하였으며 $(\mathrm{P}<0.05)$, 복강지방축적율은 암 - 수 전체평균 에서 $0.2 \%$ 첨가구가 무첨가구에 비하여 상당히 개선된 것으로 나타났다. 계육의 가열 감량은 $0.4 \%$ 첨가구를 제외한 나머지 첨가구가 대조구 에 비하여 유의적으로 낮았으며 $(\mathrm{P}<0.05)$, 전단 력은 $0.4 \%$ 첨가구가 가열 감량과는 반대로 오 히려 높았다 $(\mathrm{P}<0.05)$.

회장과 맹장내의 미생물의 변화는 전체적으 로 처리간 통계적 유의성은 보이지 않았으나, 회장과 맹장내의 유산균 수에 있어서는 첨가구 가 무첨가구에 비하여 다소 증가되는 경향을 나타내었다.

본 연구의 결과를 종합해 보면, 육계초기부 터 급여된 복합생균제가 육계후기에 그 균총이 장내에 정착하게 됨으로 장내 유해세균의 수를 감소시키고, 영양소 흡수에 최적의 조건을 조 성하여 생산성 향상을 가져올 수 있을 것으로 사료된다.

\section{$\mathrm{V}$ 인 용 문 헌}

1. Arends, L. G. 1981. Influence of L. acidophilus administered via the drinking water on broiler performance. Poultry Sci. 60:1617(Abstract).

2. Burkett R. F., Thayer, R. H. and Morrison, R. D. 1977. Supplementing market broiler rations with Lactobacillus and live yeast cultures. In : Animal science agricultural reasarch report. Oklahoma State University and USDA. USA.

3. Chiang, S. H. and Hsieh, W. M. 1995. Effect of direct-fed microorganisms on broiler growth performance and litter ammonia level. Asian-Australian Journal of Animal Science. 8:159-162.

4. Cranwell, P. D., Nokes, D. E. and Hill, K. J. 1976. Gastric secretion and fermentation in the suckling pig. Br. J. Nutr. 36:71.

5. Fuller, R. 1989. Probiotics in man and animals. J. Appl. Bacteriol. 66:365-378.

6. Gilliland, S. E. 1987. Influence of bile tolerance in Lactobacilli used as dietary adjunct. In Biotech- nology in the Feed Industry ed. Lyons, T.P. p.149-155. Kentucky, USA: Alltech Feed Co.

7. Jin, L. Z., Ho, Y. W., Abdullah, N. and Jalaludin, S. 1996. Influence of dried Bacillus subtillis and Lactobacilli cultures on intestinal microflora and performance in broilers. Asian-Australasian J. Anim. Sci. 9:397-403.

8. Jin, L. Z., Ho, Y. W., Abdullah, N. and Jalaludin, S. 1998. Growth performance, intestinal microbial populations, and serum cholesterol of broilers fed diets containing Lactobacillus cultures. Poult. Sci. 77:1259-1265.

9. Juven, B. J., Meinersmann, R. J. and Stern, N. J. 1991. Antagonistic effects of Lactobacilli and pediococci to control intestinal colonization by human enteropathogens in live poultry. J. Appl. Bacteriol. 70:95-103.

10. Maiolino, R., Fioretti, A., Menna, L. F. and Meo, C. 1992. Research on the efficiency of probiotics in diets for broiler chickens. Nutrition Abstracts and Reviews Series B. 62:482.

11. Mohan B., Kadirvel, R., Natarahan, A. and Bhaskaran, M. 1996. Effect of probiotic supplementation on growth nitrogen utilization and serum cholesterol in broilers. Br. Poult. Sci. 37:395-401.

12. National Research Council, 1994. Nutrient requirements of poultry. 9th ed. National Academic Press, Washington, DC. USA.

13. SAS Institute, 1996. SAS/STAT ${ }^{\circledR}$ User's Guide, Release 6.12 Edition. SAS Institute Inc., Cary, NC. USA.

14. Tortuero, F. 1973. Influence of the implantation of Lactobacillus acidophilus in chicks on the growth, feed conversion, malabsorption of fats syndrome and intestinal flora. Poult. Sci. 52:197-203.

15. Watkins, B. A. and Kratzer, F. H. 1983. Effect of oral dosing of Lactobacillus strains on gut colonization and liver biotin in broiler chicks. Poult. Sci. 62:2088-2094.

16. Watkins, B. A. and Kratzer, F. H. 1984. Drinking water treatment with a commercial preparation of a concentrated Lactobacillus culture for broiler chickens. Poult. Sci. 63:1671-1673.

17. White, F., Wenham, G., Sharman, G. A., Jones, A. S., Rattray, E. A. and McDonald, I. 1969. Stomach function in relation to a scour syndrome in the 
piglet. Br. J. Nutr. 23:847-858.

18. Yeo, J. and Kim, K. I. 1997. Effect of feeding diets containing an antibiotic, a probiotic, or yucca extract on growth and intestinal urease activity in broiler chicks. Poult. Sci. 76:381-385.

19. 김상호, 박수영, 유동조, 나재천, 최철한, 박용윤, 이상진, 류경선. 2000. 육계 생산성 및 맹장내 미 생물에 대한 유산균의 첨가 효과. 한국가금학회 지. 27:37-41.

20. 김상호. 2002. 가금맹장 유산균의 생균제적 가치 규명, 전북대학교 박사학위 논문.

21. 남궁환, 손익환, 정진성, 백인기. 1986. 생균제와 항생제가 병아리의 성장과 장내 세균총에 미치는
영향. 한국가금학회지. 13:49-55.

22. 노선호, 이찬호, 최윤재, 한인규. 1994. 항생제, 효소제, 효모제, 생균제 및 $\beta$-agonist가 육계의 성 장과 영양소 이용율에 미치는 효과. 한국동물자 원과학회지. 36(6):630-638.

23. 류경선, 박홍석. 1998. 생균제의 급여가 육계의 생산성과 장내 미생물의 변화에 미치는 영향. 한 국가금학회지. 25(1):31-37.

24. 박수영. 2001. 유산균의 급여가 육계의 생산성 및 계사내 환경에 미치는 영향, 전북대학교 석사 학위 논문.

(접수일자 : 2004. 1. 5. / 채택일자 : 2004. 6. 11.) 